\title{
Yersinia aldovae (Formerly Yersinia enterocolitica-Like Group X2): a New Species of Enterobacteriaceae Isolated from Aquatic Ecosystems
}

\author{
HERVÉ BERCOVIER, ${ }^{1} \dagger$ ARNOLD G. STEIGERWALT,${ }^{2}$ ANNIE GUIYOULE, ${ }^{1}$ GERALDINE HUNTLEY-CARTER,${ }^{3}$ \\ AND DON J. BRENNER ${ }^{2 *}$
}

Centre National des Yersinia, Institut Pasteur, 75724 Paris, Cedex 15, France, ${ }^{1}$ and Molecular Biology Laboratory, Biotechnology Branch, ${ }^{2}$ and Enteric Laboratory Section, Enteric Diseases Branch, ${ }^{3}$ Division of Bacterial Diseases, Center for Infectious Diseases, Centers for Disease Control, Atlanta, Georgia 30333

\begin{abstract}
Previously, a group of 40 Yersinia enterocolitica-like strains that were isolated from water and fish were called group X2. These strains produced acid from L-rhamnose, did not ferment sorbose, cellobiose, melibiose, or raffinose, and rarely fermented sucrose ( $5 \%$ in $48 \mathrm{~h}, 10 \%$ in 7 days). This pattern of reactions separated group X2 strains from Yersinia enterocolitica, Yersinia intermedia, Yersinia frederiksenii, and Yersinia kristensenii. Positive reactions for acetoin production (Voges-Proskauer test), ornithine decarboxylase, and lack of acid production from melibiose distinguished group X2 strains from both Yersinia pseudotuberculosis and Yersinia pestis. Group X2 strains exhibited variable reactions only in tests for citrate utilization, hydrolysis of Tween 80 , and acid production from maltose. Genetically, group X2 strains formed a single deoxyribonucleic acid hybridization group with an average level of relatedness of $86 \%$ or more $\left(86 \%\right.$ as determined by the $\mathrm{S} 1$ method at $60^{\circ} \mathrm{C}$ or by the hydroxyapatite method at $75^{\circ} \mathrm{C}$ and $92 \%$ as determined by the hydroxyapatite method at $60^{\circ} \mathrm{C}$ ). The level of divergence among related sequences in $60^{\circ} \mathrm{C}$ reactions was $0.5 \%$, as determined by the hydroxyapatite method. The relatedness of group X2 strains to other Yersinia species was 42 to $73 \%$ in $60^{\circ} \mathrm{C}$ reactions. The divergence in these reactions was 11.0 to $15.5 \%$, and the relatedness to other yersiniae in $75^{\circ} \mathrm{C}$ reactions was 21 to $38 \%$. Group X2 strains were 11 to $32 \%$ related to 67 species of the Enterobacteriaceae that belonged to genera other than Yersinia. On the basis of these biochemical and genetic data, we believe that group X2 represents a single new species in the genus Yersinia. The name Yersinia aldovae sp. nov. is proposed for this species. The type strain of $Y$. aldovae is strain CNY 6005 (= CDC 669-83 = ATCC 35236).
\end{abstract}

Strains that resembled Yersinia enterocolitica but were atypical by virtue of acid production from L-rhamnose and negative reactions for fermentation of sorbose, cellobiose, melibiose, and usually sucrose were described as group X2 strains by Bercovier et al. (3). Subsequently, Brenner et al. showed that strain CNY $6005^{\mathrm{T}}$ ( $\mathrm{T}=$ type strain), representing group $\mathrm{X} 2$, was substantially related to, but genetically distinct from, all Yersinia species, as determined by deoxyribonucleic acid (DNA) hybridization (8).

In this report we describe the biochemical characteristics and sources of 40 group X2 strains and the levels of DNA relatedness among 28 of these strains. We show that group $\mathrm{X} 2$ strains do, in fact, constitute a new species in the genus Yersinia. The name Yersinia aldovae sp. nov. is proposed for this new species.

\section{MATERIALS AND METHODS}

Bacterial strains. The $40 Y$. aldovae strains which we studied were sent to the Centre National des Yersinia $(\mathrm{H} . \mathrm{H}$. Mollaret, Institut Pasteur, Paris, France) from Czechoslovakia and Norway as atypical $Y$. enterocolitica-like strains. The origins and serological and phage-typing characteristics of these strains are shown in Table 1 . The strains representing other Yersinia species and other genera of the Enterobacteriaceae that were used in the DNA hybridization studies

\footnotetext{
* Corresponding author.

† Present address: Department of Clinical Microbiology, The Hebrew University, Hadassah Medical School, Jerusalem, Israel.
}

have all been deposited in the American Type Culture Collection, Rockville, Md. All bacteria were cultivated either at $28^{\circ} \mathrm{C}$ (most Yersinia strains) or at $36^{\circ} \mathrm{C}$ and were maintained on nutrient agar.

Cultural and biochemical characteristics. The colonial morphology of $Y$. aldovae was observed after 2 days of aerobic growth at $28^{\circ} \mathrm{C}$ on petri plates containing nutrient agar. The flagella of $Y$. aldovae strain CNY $6005^{\mathrm{T}}$ were studied by light microscopy after cells grown overnight at $28^{\circ} \mathrm{C}$ on semisolid nutrient agar were stained with Rhodes flagellum strain. The biochemical tests were done as previously described $(1,2$, 12). Unless otherwise stated, the biochemical tests were done at $28^{\circ} \mathrm{C}$. Hafnia-specific bacteriophage 1672 of Guinée and Valkenburg was used as described previously (11).

DNA methods. DNA was isolated by the methods of Brenner et al. and Hickman et al. $(7,13)$. The guanine-pluscytosine content of $Y$. aldovae strain CNY $6005^{\mathrm{T}}$ DNA was determined by optical denaturation of high-molecular-weight DNA diluted in $0.1 \times \mathrm{SSC}(1 \times \mathrm{SSC}$ is $0.15 \mathrm{M} \mathrm{NaCl}$ plus 0.015 $M$ sodium citrate) (14). Using the equation of Owen et al. (15), we calculated the base compositions; these were determined in triplicate, and Escherichia coli B DNA was included as a control in each determination (the thermal denaturation midpoint of Escherichia coli B DNA in $0.1 \times \mathrm{SSC}$ was $75.5^{\circ} \mathrm{C}$ ). DNAs from $Y$. aldovae strains CNY $6005^{\mathrm{T}}$ and CNY 7618 were labeled with ${ }^{32} \mathrm{PO}_{4}$ in vivo or with ${ }^{3} \mathrm{H}$ in vitro $(7,13)$. DNA hybridization was done first at $60^{\circ} \mathrm{C}$ by using the $\mathrm{S} 1$ endonuclease method and diethylaminoethyl cellulose filters, as described by Popoff and Coynault (16). In these experiments DNA from $Y$. aldovae $\mathrm{CNY} 6005^{\mathrm{T}}$ was labeled 
TABLE 1. Origins and serological and phage typing characteristics of the $40 \mathrm{Y}$. aldovae strains studied

\begin{tabular}{|c|c|c|c|c|c|c|}
\hline Laboratory strain no. & CNY strain no. ${ }^{a}$ & Habitat & Country $^{b}$ & Sent by: & Serogroup & $\overline{\text { Phage type }}$ \\
\hline 1 & $6005^{T}$ & Drinking water & $\mathrm{C}$ & E. Aldova & $\mathrm{NT}^{c}$ & $\mathrm{X}_{\mathrm{o}}$ \\
\hline 2 & 6679 & Drinking water & $\mathrm{C}$ & E. Aldova & 17 & $X_{o}$ \\
\hline 3 & 7089 & Surface water & $\mathrm{C}$ & E. Aldova & 17 & $X_{o}$ \\
\hline 4 & 7090 & Drinking water & $\mathrm{C}$ & E. Aldova & 17 & $\mathrm{X}_{\mathrm{o}}$ \\
\hline 5 & 7091 & Drinking water & $\mathrm{C}$ & E. Aldova & 17 & $\mathrm{X}_{\mathrm{o}}$ \\
\hline 6 & 7092 & Drinking water & $\mathrm{C}$ & E. Aldova & NT & $X_{0}$ \\
\hline 7 & 7096 & River & $\mathrm{C}$ & E. Aldova & NT & XI \\
\hline 8 & 7109 & Water & $\mathrm{C}$ & E. Aldova & NT & $\mathrm{X}_{\mathrm{z}}$ \\
\hline 9 & 7111 & Surface water & $\mathrm{C}$ & E. Aldova & 17 & $\mathrm{X}_{\mathrm{o}}$ \\
\hline 10 & 7112 & Surface water & $\mathrm{C}$ & E. Aldova & 7,8 & $\mathrm{X}_{\mathrm{z}}$ \\
\hline 11 & 7328 & Drinking water & $\mathrm{C}$ & E. Aldova & 7,8 & $\mathrm{X}_{\mathrm{o}}$ \\
\hline \multirow[t]{2}{*}{12} & 7330 & Swimming & & & & \\
\hline & & pool & $\mathrm{C}$ & E. Aldova & NT & $\mathrm{X}_{\mathrm{z}}$ \\
\hline 13 & 7331 & Surface water & $\mathrm{C}$ & E. Aldova & NT & $X_{z}$ \\
\hline 14 & 7332 & Surface water & $\mathrm{C}$ & E. Aldova & NT & $\mathrm{X}_{\mathrm{z}}$ \\
\hline 15 & 7618 & Fish & $\mathbf{N}$ & G. Kapperud & NT & $\mathrm{X}_{\mathrm{z}}$ \\
\hline 16 & 7622 & Fish & $\mathrm{N}$ & G. Kapperud & NT & $X_{\mathrm{o}}^{2}$ \\
\hline 17 & 7632 & Fish & $\mathbf{N}$ & G. Kapperud & NT & $X_{z}$ \\
\hline 18 & 7683 & Water & $\mathrm{C}$ & E. Aldova & 22 & $\mathrm{X}_{\mathrm{z}}$ \\
\hline 19 & 7898 & Water & $\mathrm{N}$ & G. Langeland & NT & $X_{o}$ \\
\hline 20 & 7927 & Water & $\mathbf{N}$ & G. Langeland & NT & $\mathrm{X}_{\mathrm{o}}$ \\
\hline 21 & 7928 & Water & $\mathrm{N}$ & G. Langeland & NT & $\mathrm{X}_{\mathrm{o}}$ \\
\hline 22 & 7970 & Water & $\mathbf{N}$ & G. Langeland & NT & $\mathrm{X}_{\mathrm{z}}$ \\
\hline 23 & 7971 & Water & $N$ & G. Langeland & NT & $x_{o}$ \\
\hline 24 & 8285 & Water & $\mathbf{N}$ & G. Langeland & 6,31 & $\mathrm{X}_{\mathrm{z}}$ \\
\hline 25 & 8286 & Water & $\mathrm{N}$ & G. Langeland & 6,31 & $\mathrm{X}_{\mathrm{z}}$ \\
\hline 26 & 8287 & Water & $\mathbf{N}$ & G. Langeland & NT & $\mathrm{X}_{\mathrm{z}}$ \\
\hline 27 & 8288 & Water & $\mathrm{N}$ & G. Langeland & 6,31 & $\mathrm{X}_{\mathrm{z}}$ \\
\hline 28 & 8290 & Water & $\mathbf{N}$ & G. Langeland & NT & $x_{o}$ \\
\hline 29 & 8616 & Drinking water & $\mathrm{C}$ & E. Aldova & 17 & $x_{0}$ \\
\hline 30 & 8619 & Drinking water & $\mathrm{C}$ & E. Aldova & NT & $X_{o}$ \\
\hline 31 & 8626 & Drinking water & $\mathrm{C}$ & E. Aldova & NT & $\mathrm{X}_{\mathrm{z}}$ \\
\hline 32 & 8631 & Drinking water & $\mathrm{C}$ & E. Aldova & NT & $\mathrm{X}_{\mathrm{o}}$ \\
\hline 33 & 8632 & Drinking water & $\mathrm{C}$ & E. Aldova & NT & $\mathrm{X}_{\mathrm{o}}$ \\
\hline 34 & 8780 & Drinking water & $\mathrm{C}$ & E. Aldova & 6,30 & $\mathrm{X}_{\mathrm{o}}$ \\
\hline 35 & 8784 & Drinking water & $\mathrm{C}$ & E. Aldova & 21 & $X_{z}$ \\
\hline 36 & 8789 & Drinking water & $\mathrm{C}$ & E. Aldova & NT & $\mathrm{X}_{\mathrm{o}}$ \\
\hline 37 & 8790 & Drinking water & $\mathrm{C}$ & E. Aldova & 17 & $x_{o}$ \\
\hline 38 & 8791 & Drinking water & $\mathrm{C}$ & E. Aldova & 17 & $\mathrm{X}_{\mathrm{z}}$ \\
\hline 39 & 8793 & Drinking water & $\mathrm{C}$ & E. Aldova & 6,30 & $X_{o}$ \\
\hline 40 & 9553 & Drinking water & $\mathrm{C}$ & E. Aldova & NT & $\mathrm{X}_{\mathrm{o}}$ \\
\hline
\end{tabular}

${ }^{a}$ CNY, Centre National des Yersinia (H. H. Mollaret, Institut Pasteur, Paris, France).

${ }^{b}$ C, Czechoslovakia; N, Norway.

${ }^{c}$ NT, Untypable.

in vitro with $\left[{ }^{3} \mathrm{H}\right]$ thymidine. Subsequently, DNA hybridization was done by the hydroxyapatite method at 60 and $75^{\circ} \mathrm{C}$, using DNAs from $Y$. aldovae strains CNY $6005^{\mathrm{T}}$ and $\mathrm{CNY}$ 7618 that were labeled with ${ }^{32} \mathrm{PO}_{4}$ in vivo.

\section{RESULTS}

Phenotypic characteristics. The 40 strains of $Y$. aldovae examined gave mostly homogeneous reactions in biochemical tests done at $28^{\circ} \mathrm{C}$ (Table 2). The characteristics common to all of the strains studied are listed below. A total of 36 strains did not ferment sucrose; 2 strains fermented sucrose within $48 \mathrm{~h}$, and 2 strains fermented sucrose after 4 days. Utilization of citrate (Simmons), acid production from maltose, and hydrolysis of Tween 80 were independently variable reactions in the $40 Y$. aldovae strains. Two strains were nonmotile at $28^{\circ} \mathrm{C}$, and two other strains gave negative reactions for urease. A single strain gave a negative test for iinositol. Like other Yersinia species, especially the L-rhamnose-fermenting species Yersinia intermedia and Yersinia frederiksenii, when $Y$. aldovae was incubated at $36 \pm 1{ }^{\circ} \mathrm{C}$, it exhibited negative or delayed positive reactions in tests for
L-rhamnose, D-xylose, i-inositol, the Voges-Proskauer reaction, Simmons citrate, ornithine decarboxylase, beta-galactosidase ( $o$-nitrophenyl- $\beta$-D-galactopyranoside), and, of course, motility. These data (except the motility, methyl red, Voges-Proskauer, beta-xylosidase, and Simmons citrate data) are not shown for all strains, but the results of the $36 \pm$ $1{ }^{\circ} \mathrm{C}$ reactions for representative strains CNY $6005^{\mathrm{T}}$ and CNY 7618 are shown in Table 2 .

Of the $40 \mathrm{Y}$. aldovae strains, 17 were typable in slide agglutination tests for $\mathrm{O}$ antigens by the scheme of Wauters et al. (19). Eight strains were serogroup 0:17 strains, followed by decreasing numbers of strains in serogroups $\mathrm{O}: 6,31,0: 6,30,0: 7,8,0: 21$, and $0: 22$ (Table 1). All but 1 of the $\mathbf{4 0}$ strains belonged to either phage type $X_{z}$ or phage type $\mathrm{X}_{0}$; these phage types consist of bacteriophages that are isolated from sewage, not of specific temperate bacteriophages that are isolated from $Y$. enterocolitica (Table 1).

Genetic characteristics. The guanine-plus-cytosine content of DNA from $Y$. aldovae CNY $6005^{\mathrm{T}}$ was $48 \mathrm{~mol} \%$. DNA relatedness studies were done by using radiolabeled DNAs from $Y$, aldovae $\mathrm{CNY} 6005^{\mathrm{T}}$ and $\mathrm{CNY}$ 7618. The levels of 
TABLE 2. Biochemical characteristics of $Y$. aldovae strains ${ }^{a}$

\begin{tabular}{|c|c|c|c|c|c|}
\hline \multirow[t]{2}{*}{ Test } & \multirow{2}{*}{$\begin{array}{c}\% \text { of } 40 \mathrm{Y} \text {. aldovae } \\
\text { strains positive at } 28^{\circ} \mathrm{C} \\
\text { within } 72 \mathrm{~h}\end{array}$} & \multicolumn{2}{|c|}{$\begin{array}{l}\text { Reaction of } \\
\text { type strain } \\
\text { CNY } 6005 \text { at: }\end{array}$} & \multirow[t]{2}{*}{$\begin{array}{l}\text { Strains giving reaction opposite } \\
\text { that of the type strain at } 28^{\circ} \mathrm{C}\end{array}$} & \multirow{2}{*}{$\begin{array}{l}\text { Reaction of sucrose- } \\
\text { positive reference } \\
\text { strain CNY } 7618 \\
\text { at } 36^{\circ} \mathrm{C}\end{array}$} \\
\hline & & $28^{\circ} \mathrm{C}$ & $36^{\circ} \mathrm{C}$ & & \\
\hline Motility & 95 & + & - & $22,23^{b}$ & - \\
\hline Urease & 95 & + & $(+)$ & 20,21 & + \\
\hline Indole & 0 & - & - & & - \\
\hline Voges-Proskauer & 100 & + & - & & - \\
\hline Citrate (Simmons) & 75 & + & - & $2,8-10,13,22,24,28,33,34$ & - \\
\hline Lysine decarboxylase & 0 & - & - & & - \\
\hline Ornithine decarboxylase & 100 & + & + & & - \\
\hline Beta-galactosidase (ONPG) ${ }^{c}$ & 100 & + & - & & $(+)$ \\
\hline Lipase (Tween 80) & 60 & + & - & $\begin{array}{c}7-10,12,15,18,19,22 \\
24-26,28,31,32,40\end{array}$ & - \\
\hline \multicolumn{6}{|l|}{ Acid production from: } \\
\hline Sucrose & $5(5)$ & - & - & $15,16,22,23$ & + \\
\hline L-Rhamnose & $98(2)$ & + & $(+)$ & & - \\
\hline D-Cellobiose & 0 & - & - & & - \\
\hline L-Sorbose & 0 & - & - & & - \\
\hline i-Inositol & 98 & + & $(+)$ & 19 & - \\
\hline Maltose & 23 & - & - & $2,15-17,19-23$ & $(+)$ \\
\hline
\end{tabular}

${ }^{a}$ Unless indicated otherwise, incubation was at $28^{\circ} \mathrm{C}$. Reactions were read after $72 \mathrm{~h}$ and 7 days. The 7 -day readings are shown in parentheses when cultures were negative after 3 days and positive after 7 days. + , positive within 3 days; - , negative after 7 days; $(+)$, positive between 3 and 7 days.

${ }^{b}$ Strain numbers used in Table 1.

${ }^{c}$ ONPG, $o$-Nitrophenyl- $\beta$-D-galactopyranoside.

DNA relatedness among $28 Y$. aldovae strains are shown in Table 3. All of the $Y$. aldovae strains belonged to a single group, in which the average level of DNA relatedness was $85 \%$ or more. Specifically, the average level of relatedness of $Y$. aldovae strain CNY $6005^{\mathrm{T}}$ to other $Y$. aldovae strains was $85 \%$ (range, 72 to $94 \%$ ) in S1 hybridization experiments done at $60^{\circ} \mathrm{C}$. In hydroxyapatite hybridization experiments, $Y$. aldovae CNY $6005^{\mathrm{T}}$ showed $92 \%$ average relatedness to other $Y$. aldovae strains (range, 79 to $100 \%$ ). The level of divergence in the related sequences was $0.5 \%$ (range, 0.0 to $1.5 \%)$, and the average level of relatedness at the stringent $75^{\circ} \mathrm{C}$ incubation temperature, at which only very closely related sequences can reassociate, was $85 \%$ (range, 78 to $92 \%$ ). In hydroxyapatite experiments done with radiolabeled DNA from $Y$. aldovae CNY 7618, a sucrose-positive strain, the average level of relatedness to other $Y$. aldovae strains was $85 \%$ (range, 72 to $99 \%$ ) at $60^{\circ} \mathrm{C}$ and $93 \%$ (range, 81 to $100 \%$ ) at $75^{\circ} \mathrm{C}$. Thus, the sucrose-negative and sucrosepositive strains are biogroups of the same species.

The levels of DNA relatedness of $Y$. aldovae to other Yersinia species and to other species in the family Enterobacteriaceae are shown in Table 4. Y. aldovae was 64 to $73 \%$ related to strains from various biogroups of $Y$. enterocolitica, including biogroup 5 , which is usually sucrose negative. The level of divergence in the related sequences in these reactions was 11.0 to $13.0 \%$, and the level of relatedness dropped to $38 \%$ in one case where the reaction was done at $75^{\circ} \mathrm{C}$. $Y$. aldovae was also highly related to two strains of $Y$. enterocolitica biogroup $\mathrm{X} 1$, another sucrosenegative group (3). At $60^{\circ} \mathrm{C}$ these groups were 68 to $69 \%$ related, but the levels of relatedness fell to 32 to $34 \%$ in reactions done at $75^{\circ} \mathrm{C}$. $Y$. aldovae was $45 \%$ related to $Y$. frederiksenii IP 867 and 64 to $67 \%$ related to three other $Y$. frederiksenii strains (these four $Y$. frederiksenii strains represented three different hybridization groups within this species [18]). The levels of divergence in these reactions were 12.0 to $15.0 \%$, and the levels of relatedness in $75^{\circ} \mathrm{C}$ reactions were 21 to $29 \%$. Y . aldovae was $59 \%$ related to the type strains of both $Y$. intermedia and Yersinia kristensenii. The level of divergence in these reactions was $11.5 \%$, and the levels of relatedness fell to 27 to $30 \%$ in $75^{\circ} \mathrm{C}$ reactions. Somewhat lower levels of relatedness (42 to $44 \%$ ) were observed between $Y$. aldovae and strains of Yersinia pseudotuberculosis and Yersinia ruckeri. It was not necessary to test Yersinia pestis because this species is 95 to $100 \%$ related to $Y$. pseudotuberculosis (4). The levels of relatedness of $Y$. aldovae to other members of the Enterobacteriaceae were 11 to $32 \%$ (Table 4 ).

\section{DISCUSSION}

Our $Y$. aldovae strains corresponded to the previously described group $X 2$, which was represented by strain CNY $6005^{\mathrm{T}}\left(=\right.$ IP $\left.6005^{\mathrm{T}}\right)(1,3,8)$. These $Y$. aldovae strains gave homogeneous reactions for most biochemical tests when they were grown at 25 to $28^{\circ} \mathrm{C}$, but exhibited delayed, variable, or negative reactions in several key diagnostic tests when they were grown at 35 to $37^{\circ} \mathrm{C}$ (Table 2). These tests included the L-rhamnose, i-inositol, beta-galactosidase, Voges-Proskauer, Simmons citrate, ornithine decarboxylase, and motility tests. When done at 35 to $37^{\circ} \mathrm{C}$, these reactions can confuse identification and may lead to misidentification of $Y$. aldovae as a metabolically inactive species, such as a Shigella species or metabolically inactive Escherichia coli. The presence of small colonies (and often medium-sized colonies on the same plate, obtained from streaking out of a single colony), a positive urease test, and the absence of phenylalanine deaminase, arginine dihydrolase, and lysine decarboxylase direct identification toward the genus Yersinia. Differentiation of $Y$. aldovae from urease-positive Hafnia alvei strains (about $4 \%$ of $H$. alvei strains are urease positive $[10,17])$ requires special mention. One of us (H.B.) has received strains that were misidentified as Yersinia and were, in fact, urease-positive $H$. alvei strains that gave negative lysine decarboxylase tests at $36^{\circ} \mathrm{C}$. These $H$. alvei strains were distinguished from $Y$. aldovae at $36^{\circ} \mathrm{C}$ by production of gas from $\mathrm{D}$-glucose, as well as by sensitivity 
TABLE 3. Levels of intraspecies DNA relatedness of $Y$. aldovae strains ${ }^{a}$

\begin{tabular}{|c|c|c|c|c|c|c|}
\hline \multirow{4}{*}{$\begin{array}{l}\text { Source of unlabeled } \\
\text { Y. aldovae DNA }\end{array}$} & \multicolumn{6}{|c|}{ Source of labeled DNA } \\
\hline & \multicolumn{4}{|c|}{ Y. aldovae $\mathrm{CNY} 6005^{\mathrm{T}}$} & \multirow{2}{*}{\multicolumn{2}{|c|}{$\begin{array}{c}\text { Y. aldovae CNY } 7618 \\
\text { RBR (\%, HA method) at: }\end{array}$}} \\
\hline & \multicolumn{3}{|c|}{ RBR $(\%)$ at $60^{\circ} \mathrm{C}$} & \multirow{2}{*}{$\begin{array}{l}\mathrm{RBR}(\%) \text { at } 75^{\circ} \mathrm{C} \\
\text { (HA method) }\end{array}$} & & \\
\hline & S1 method & HA method & $\bar{D}$ & & $60^{\circ} \mathrm{C}$ & $75^{\circ} \mathrm{C}$ \\
\hline CNY $6005^{\mathrm{T}}$ & 100 & 100 & 0.0 & 100 & 80 & 88 \\
\hline CNY 6679 & 89 & ND & ND & ND & ND & ND \\
\hline CNY 7089 & 85 & 94 & 0.0 & 91 & ND & ND \\
\hline CNY 7090 & 80 & ND & ND & ND & ND & ND \\
\hline CNY 7091 & 89 & 100 & ND & 89 & 81 & 91 \\
\hline CNY 7092 & 89 & ND & ND & ND & ND & ND \\
\hline CNY 7096 & 83 & 99 & ND & 83 & 74 & 96 \\
\hline CNY 7109 & 84 & 100 & ND & 84 & 86 & 98 \\
\hline CNY 7111 & 94 & ND & ND & ND & ND & ND \\
\hline CNY 7112 & 88 & 98 & ND & 83 & 72 & 92 \\
\hline CNY 7328 & 93 & ND & ND & ND & ND & ND \\
\hline CNY 7330 & 84 & ND & ND & ND & ND & ND \\
\hline CNY 7331 & 89 & 89 & 0.0 & 84 & 80 & 90 \\
\hline CNY 7332 & 87 & ND & ND & ND & ND & ND \\
\hline CNY 7618 & 88 & 94 & 0.0 & 84 & 100 & 100 \\
\hline CNY 7622 & 78 & 83 & ND & 89 & 88 & 92 \\
\hline CNY 7632 & 74 & 79 & 1.5 & 86 & 99 & 96 \\
\hline CNY 7683 & 89 & ND & ND & ND & ND & ND \\
\hline CNY 7898 & 78 & 83 & 1.5 & 78 & 92 & 94 \\
\hline CNY 7927 & 72 & ND & ND & ND & ND & ND \\
\hline CNY 7928 & 79 & 99 & ND & 80 & ND & 81 \\
\hline CNY 7970 & 87 & 100 & ND & 83 & 84 & 95 \\
\hline CNY 7971 & 74 & ND & ND & ND & ND & ND \\
\hline CNY 8285 & 89 & ND & ND & ND & ND & ND \\
\hline CNY 8286 & 92 & 83 & ND & 92 & 99 & 100 \\
\hline CNY 8287 & 92 & ND & ND & ND & ND & ND \\
\hline CNY 8288 & 88 & ND & ND & ND & ND & ND \\
\hline CNY 8290 & 89 & ND & ND & ND & ND & ND \\
\hline
\end{tabular}

${ }^{a}$ S1 method, Diethylaminoethyl cellulose S1 nuclease hybridization assay; HA method, hydroxyapatite hybridization assay; RBR, relative binding ratio; $\mathrm{D}$, divergence. For the $\mathrm{S} 1$ nuclease assay the following formula was used: relative binding ratio $=$ (percentage of heterologous DNA bound to diethylaminoethyl cellulose filter)/(percentage of homologous DNA bound to diethylaminoethyl cellulose filter) $\times 100$. For the hydroxyapatite assay the formula used was: relative binding ratio $=$ (percentage of heterologous DNA bound to hydroxyapatite)/(percentage of homologous DNA bound to hydroxyapatite) $\times 100$. Divergence was calculated on the assumption that each $1^{\circ} \mathrm{C}$ decrease in the stability of a heterologous DNA duplex compared with the stability of a homologous DNA duplex was caused by approximately $1 \%$ unpaired nucleotide bases within the heteroduplex. Divergence is expressed to the nearest $0.5 \%$. ${ }^{3} \mathrm{H}$-labeled DNA from Y. aldovae $\mathrm{CNY} 6005^{\mathrm{T}}$ was used in the S1 nuclease experiments. Each reaction was done twice on duplicate filters. The values given are averages of four values, which did not differ by more than $2 \%$. The average level of homologous binding was $81 \%$. Approximately $3 \%$ of the labeled DNA bound to diethylaminoethyl cellulose filters in the absence of unlabeled DNA. This control value was subtracted from the heterologous binding values before normalization. DNAs from $Y$. aldovae strains CNY $6005^{\mathrm{T}}$ and $\mathrm{CNY} 7618$, labeled in vivo with ${ }^{32} \mathrm{PO}_{4}$, were used in the hydroxyapatite hybridization experiments. The average level of binding in homologous reactions was $75 \%$ for both labeled DNA preparations. Each reaction was done twice. Approximately $5 \%$ of the labeled DNA bound to the hydroxyapatite in the absence of unlabeled DNA. This control value was subtracted from the heterologous binding values before normalization.

${ }^{b}$ ND, Not done.

to a Hafnia-specific bacteriophage (11). At $28^{\circ} \mathrm{C}$, the reactions described above, as well as a positive lysine decarboxylase test and a negative test for acid production from $D$ sorbitol, distinguished $H$. alvei from $Y$. aldovae.

The variability in biochemical test results for $Y$. aldovae obtained at $36 \pm 1{ }^{\circ} \mathrm{C}$ compared with the results obtained at $28^{\circ} \mathrm{C}$ is found in most Yersinia species $(2,3,5,6,8,18)$. These phenotypic characteristics, especially motility at 25 to $28^{\circ} \mathrm{C}$ but not at $36 \pm 1^{\circ} \mathrm{C}$, strengthen the phenotypic resemblance of $Y$. aldovae to other Yersinia species. Practical biochemical tests that are useful for differentiating $Y$. aldovae from other Yersinia species are shown in Table 5. Y. aldovae is easily separated from the other Yersinia species that are sucrose negative or that contain sucrose-negative strains. $Y$. aldovae is separated from $Y$. kristensenii by its positive L-rhamnose reaction, negative reactions for cellobiose and sorbose, and positive Voges-Proskauer reaction. $Y$. aldovae is distinguished from $Y$. pseudotuberculosis on the bases of its positive ornithine decarboxylase and D-sorbitol reactions and its negative melibiose reaction and from $Y$. pestis by the same tests plus its positive urease reaction. It is separated from biogroup 5 of $Y$. enterocolitica (which contains sucrose-negative strains) by its positive D-sorbitol and L-rhamnose reactions and its negative cellobiose reaction. $Y$. aldovae is differentiated from $Y$. ruckeri by its positive reactions for urease and $\mathrm{D}$-sorbitol. It is also simple to differentiate $Y$. aldovae from the sucrose-positive Yersinia species by its negative sucrose reaction, as well as its negative reactions for sorbose and cellobiose (from $Y$. enterocolitica biogroups 1 through $4, Y$. intermedia, and $Y$. frederiksenii), negative indole reaction (from $Y$. intermedia, and $Y$. frederiksenii), negative melibiose reaction (from $Y$. intermedia), and positive $\mathrm{L}$-rhamnose reaction (from $Y$. enterocolitica biogroups 1 through 4).

DNA hybridization studies showed that the $Y$. aldovae strains are highly interrelated, forming a good genospecies 
TABLE 4. Levels of DNA relatedness of $Y$. aldovae to species of Yersinia and other genera in the Enterobacteriaceae ${ }^{a}$

\begin{tabular}{|c|c|c|c|c|c|c|c|}
\hline \multirow{2}{*}{ Source of unlabeled DNA } & \multicolumn{3}{|c|}{$\begin{array}{l}\text { Relatedness to }{ }^{32} \mathrm{PO}_{4} \text {-labeled } \\
\text { Y. aldovae CNY } 6005^{\mathrm{T}} \text { DNA }\end{array}$} & \multirow{2}{*}{ Source of unlabeled DNA } & \multicolumn{3}{|c|}{$\begin{array}{l}\text { Relatedness to }{ }^{32} \mathrm{PO}_{4}-\text { labeled } \\
Y \text {. aldovae } \mathrm{CNY} 6005^{\mathrm{T}} \text { DNA }\end{array}$} \\
\hline & $\begin{array}{l}\mathrm{RBR}(\%) \\
\text { at } 60^{\circ} \mathrm{C}\end{array}$ & $\mathrm{D}(\%)$ & $\begin{array}{l}\mathrm{RBR}(\%) \\
\text { at } 75^{\circ} \mathrm{C}\end{array}$ & & $\begin{array}{l}\mathrm{RBR}(\%) \\
\text { at } 60^{\circ} \mathrm{C}\end{array}$ & $\mathrm{D}(\%)$ & $\begin{array}{l}\mathrm{RBR}(\%) \\
\text { at } 75^{\circ} \mathrm{C}\end{array}$ \\
\hline $\begin{array}{l}\text { Y. enterocolitica } 2525-75 \text { (biogroup } \\
\text { unknown) }\end{array}$ & 73 & 12.5 & & $\begin{array}{l}\text { Enterobacter amnigenus } 1325-79 \\
\text { Kluyvera ascorbata } 408-78\end{array}$ & $\begin{array}{l}23 \\
23\end{array}$ & & \\
\hline Y. enterocolitica $497-70$ (biogroup 1) & 70 & 11.0 & 38 & Erwinia salicis $\mathrm{ES} 102$ & 22 & & \\
\hline Y. enterocolitica $500-70$ (biogroup 3 ) & 70 & 11.0 & & Erwinia amylovora EA178 & 22 & & \\
\hline Yersinia biogroup X1 strain IP 7706 & 69 & & 32 & Enterobacter agglomerans $219-71$ & 22 & & \\
\hline Yersinia biogroup X1 strain IP 7702 & 68 & & 34 & Enterobacter agglomerans $4388-71$ & 22 & & \\
\hline Y. enterocolitica IP 178 (biogroup 5) & 68 & 12.5 & & Enterobacter agglomerans $3482-71$ & 22 & & \\
\hline Y. frederiksenii IP 5960 & 67 & & 29 & Enterobacter agglomerans $3123-70$ & 22 & & \\
\hline Y. frederiksenii IP 6175 & 67 & 14.5 & & Serratia marcescens $868-57$ & 22 & & \\
\hline Y. frederiksenii $2851-77$ & 64 & 15.0 & & Citrobacter amalonaticus ATCC & 22 & & \\
\hline Y. enterocolitica IP 211 (biogroup 2) & 64 & 13.0 & & 25406 & & & \\
\hline Y. kristensenii IP 1474 & 59 & 11.5 & 30 & Cedecea neteri $621-75$ & 22 & & \\
\hline Y. intermedia IP 3953 & 59 & 11.5 & 27 & Salmonella typhimurium LT2 & 22 & & \\
\hline Y. frederiksenii IP 867 & 45 & 12.0 & 21 & Enterobacter agglomerans 1741-71 & 21 & & \\
\hline Y. ruckeri $4535-69$ & 44 & 15.5 & & Serratia ficaria $1165-77$ & 21 & & \\
\hline Y. pseudotuberculosis $\mathrm{P} 62$ & 42 & 14.0 & & Cedecea davisae $3278-77$ & 21 & & \\
\hline Serratia fonticola $4556-71$ & 32 & & & Cedecea lapagei $485-76$ & 21 & & \\
\hline Serratia liquefaciens $446-68$ & 30 & & & Erwinia mallotivora NCPPB 2851 & 20 & & \\
\hline Erwinia cypripedii EC155 & 28 & & & Enterobacter agglomerans 6070-69 & 20 & & \\
\hline Erwinia rhapontici ER106 & 28 & & & Erwinia quercina $\mathrm{EQ} 102$ & 19 & & \\
\hline Erwinia carotovora ATCC 495 & 27 & & & Klebsiella pneumoniae 2 & 19 & & \\
\hline Enterobacter aerogenes $1627-66$ & 27 & & & Shigella boydii $\mathrm{C} 13$ 1610-55 & 19 & & \\
\hline Erwinia nigrifluens EN104 & 25 & & & Edwardsiella tarda $3592-64$ & 19 & & \\
\hline Enterobacter agglomerans $2780-70$ & 25 & & & Escherichia vulneris $2898-73$ & 19 & & \\
\hline Enterobacter agglomerans 1429-71 & 25 & & & Proteus vulgaris $\mathrm{PR} 1$ & 19 & & \\
\hline Serratia rubidaea $934-72$ & 25 & & & Enterobacter skazakii $4562-70$ & 18 & & \\
\hline Serratia plymuthica 392 & 25 & & & Escherichia hermannii $980-73$ & 18 & & \\
\hline Rahnella aquatilis $1327-79$ & 25 & & & Citrobacter diversus 1066-71 & 18 & & \\
\hline Kluyvera cryocrescens $409-78$ & 25 & & & Providencia rustigianii $132-68$ & 18 & & \\
\hline Escherichia blattae $9005-74$ & 25 & & & Enterobacter gergoviae CIP 7601 & 17 & & \\
\hline Obesumbacterium proteus $4302-74$ & 24 & & & Hafnia alvei III 329-73 & 17 & & \\
\hline Erwinia carnegieana EC186 & 24 & & & Enterobacter agglomerans $1645-71$ & 16 & & \\
\hline Enterobacter agglomerans 6003-71 & 24 & & & Providencia alcalifaciens $3370-67$ & 15 & & \\
\hline Enterobacter agglomerans $1600-71$ & 24 & & & Providencia stuartii 2896-68 & 15 & & \\
\hline Enterobacter agglomerans 5378-71 & 24 & & & Providencia rettgeri 1163 & 15 & & \\
\hline Enterobacter cloacae $1347-71$ & 24 & & & Hafnia alvei II 4510-75 & 14 & & \\
\hline Klebsiella oxytoca ATCC 13182 & 24 & & & Erwinia chrysanthemi SR32 & 14 & & \\
\hline Enterobacter agglomerans 5422-69 & 23 & & & Escherichia coli $\mathrm{K}-12$ & 12 & & \\
\hline Citrobacter freundii $460-61$ & 23 & & & Proteus myxofaciens ATCC 19692 & 12 & & \\
\hline Hafnia alvei I 5632-72 & 23 & & & Proteus mirabilis PR14 & 11 & & \\
\hline Morganella morganii ATCC 25830 & 23 & & & Erwinia rubrifaciens ER105 & 11 & & \\
\hline
\end{tabular}

${ }^{a}$ RBR, Relative binding ratio; D, divergence. See Table 3, footnote $a$, for experimental conditions.

(Table 3). Although strain CNY 7618 produced acid from sucrose, the levels of relatedness between this strain and other $Y$. aldovae strains were similar to the levels of relatedness between the more typical (sucrose-negative) strain $\mathrm{CNY} 6005^{\mathrm{T}}$ and other $Y$. aldovae strains. This proves that the sucrose-positive biogroup is part of $Y$. aldovae. The results of DNA hybridization studies done with labeled DNAs from other Yersinia species and unlabeled DNAs from group X2 strains CNY $6005^{\mathrm{T}}$ and IP 5850 have been published previously (8). In these studies $Y$. enterocolitica was 53 to $65 \%$ related to $Y$. aldovae at $60^{\circ} \mathrm{C}$ and 28 to $36 \%$ related at $75^{\circ} \mathrm{C} ; Y$. kristensenii was 60 to $66 \%$ related to $Y$. aldovae at $60^{\circ} \mathrm{C}$ and 33 to $35 \%$ related at $75^{\circ} \mathrm{C} ; Y$. frederiksenii was 43 to $56 \%$ related to $Y$. aldovae at $60^{\circ} \mathrm{C}$ and 14 to $23 \%$ related at $75^{\circ} \mathrm{C}$; and $Y$. intermedia was 51 to $57 \%$ related to $Y$. aldovae at $60^{\circ} \mathrm{C}$ and 29 to $31 \%$ related at $75^{\circ} \mathrm{C}$. Where determined, the levels of divergence in related sequences were 10 to $14 \%$ (8).

In the present study the reciprocal hybridization experiments yielded similar results (Table 4). The levels of diver- gence in related sequences were 11 to $15 \%$; the levels of relatedness in $75^{\circ} \mathrm{C}$ reactions were 21 to $38 \%$, and the levels of relatedness in $60^{\circ} \mathrm{C}$ reactions were $59 \%$ (to $Y$. kristensenii), 45 to $67 \%$ (to $Y$. frederiksenii), $59 \%$ (to $Y$. intermedia), $42 \%$ (to $Y$. pseudotuberculosis), and 64 to $73 \%$ (to $Y$. enterocolitica). The level of relatedness between $Y$. aldovae and $Y$. enterocolitica (as determined with labeled $Y$. aldovae DNA) is close to the lower level of relatedness observed between strains of a single species ( $70 \%$ or more). The higher levels of relatedness observed between these species when $Y$. aldovae DNA rather than labeled $Y$. enterocolitica DNA was used (64 to $74 \%$ compared with 53 to $65 \%$ ) might have been due to differences in genome size between strains of these two species ( $Y$. enterocolitica is 12 to $14 \%$ smaller than $Y$. aldovae). The fact that $Y$. aldovae and $Y$. enterocolitica are separate species was proven by the substantial levels of divergence present in DNA heteroduplexes (10 to 15\%) compared with the levels observed in reactions between strains of $Y$. aldovae ( 0.0 to $1.5 \%$ [Table 3]) or $Y$. enterocolitica $(0.0$ to $4.0 \%$ [8] ) and by the substantially lower levels of 
TABLE 5. Biochemical differentiation of $Y$. aldovae from other Yersinia species $^{a}$

\begin{tabular}{|c|c|c|c|c|c|c|c|c|c|}
\hline \multirow{3}{*}{ Test } & \multicolumn{9}{|c|}{ Reaction of: } \\
\hline & \multirow[b]{2}{*}{ Y. aldovae } & \multirow{2}{*}{$\begin{array}{l}Y . p s e u d o- \\
\text { tuberculosis }\end{array}$} & \multirow[b]{2}{*}{$Y$. pestis } & \multirow{2}{*}{$\begin{array}{l}\text { Y. kris- } \\
\text { tensenii }\end{array}$} & \multirow[b]{2}{*}{ Y. ruckeri } & \multicolumn{2}{|c|}{ Y. enterocolitica } & \multirow{2}{*}{$\begin{array}{l}Y . \text { inter- } \\
\text { media }\end{array}$} & \multirow{2}{*}{$\begin{array}{l}\text { Y. fred- } \\
\text { eriksenii }\end{array}$} \\
\hline & & & & & & Biogroup 5 & $\begin{array}{c}\text { Biogroups } \\
1 \text { through } 4\end{array}$ & & \\
\hline Voges-Proskauer & + & - & - & - & - & + & + & + & + \\
\hline Sucrose & - & - & - & - & - & V & + & + & + \\
\hline Cellobiose & - & - & - & + & - & + & + & + & + \\
\hline Indole & - & - & - & $\mathrm{V}$ & - & - & V & + & + \\
\hline Sorbose & - & - & - & + & ND & $\mathrm{V}$ & + & + & + \\
\hline L-Rhamnose & + & + & - & - & - & - & - & + & + \\
\hline Melibiose & - & + & $\mathrm{V}$ & - & - & - & - & + & - \\
\hline D-Sorbitol & + & - & - & + & - & - & + & + & + \\
\hline Ornithine decarboxylase & + & - & - & + & + & V & + & + & + \\
\hline Urease & + & t & - & + & - & + & + & + & + \\
\hline
\end{tabular}

${ }^{a}$ The data for $Y$. aldovae are from Table 2, the data for $Y$. ruckeri are from reference 9 , and the data for the other yersiniae are from references 3 through 6 and 18 . All of the data are for 3 days of incubation at $28^{\circ} \mathrm{C}\left(2\right.$ days of incubation at $25^{\circ} \mathrm{C}$ for $\left.Y . r u c k e r i\right)$.,$+ 90 \%$ or more of the strains positive; - less than $10 \%$ positive; $\mathrm{V}, 10$ to $89 \%$ positive; ND, test not done.

relatedness observed in $75^{\circ} \mathrm{C}$ reactions between these species ( 24 to $36 \%$ [Table 4$]$ [8]) than in reactions among strains of $Y$. aldovae ( 78 to $100 \%$ [Table 3]) or $Y$. enterocolitica $(68 \%$ to $97 \%$ [8]). For that matter, the level of relatedness among strains of either species at $60^{\circ} \mathrm{C}$ (average for $Y$. aldovae, 85 to $92 \%$ [Table 3]; average for $Y$. enterocolitica, $85 \%[8]$ ) was substantially higher than the levels obtained in reactions between strains of $Y$. aldovae and $Y$. enterocolitica (69\% average relatedness at $60^{\circ} \mathrm{C}$ with labeled $Y$. aldovae DNA and unlabeled $Y$. enterocolitica DNAs [Table 4]; 60\% average relatedness at $60^{\circ} \mathrm{C}$ with labeled $Y$. enterocolitica DNA and unlabeled $Y$. aldovae DNAs [8]).

The levels of relatedness of $Y$. aldovae to other members of the Enterobacteriaceae were substantially lower than the levels of relatedness to yersiniae, but nonetheless were significant (11 to $32 \%$ [Table 4]). The guanine-plus-cytosine content of $Y$. aldovae strain CNY $6005^{\mathrm{T}}$ DNA was $48 \mathrm{~mol} \%$, a value which is similar to the guanine-plus-cytosine contents of other Yersinia species. Therefore, we conclude that, on the basis of phenotypic and genetic characteristics, $Y$. aldovae is a new species of the Enterobacteriaceae and does indeed belong in the genus Yersinia.

It must be emphasized that, as with most other yersiniae, biochemical characterization is more definitive when test preparations are incubated at 25 to $28^{\circ} \mathrm{C}$ (the optimal growth temperature) than when they are incubated at $36 \pm 1{ }^{\circ} \mathrm{C}$. The results of biochemical tests done at $36 \pm 1^{\circ} \mathrm{C}$ are frequently misleading, because several important diagnostic tests give false-negative or delayed positive results. These false-negative findings can result in misidentification at the species level or even at the genus level. Results from this study and our previous studies have clearly shown that all Yersinia species are readily identified when they are studied at $28^{\circ} \mathrm{C}$ (3-6, 9, 18).

The 40 strains of $Y$. aldovae which we studied were all isolated from aquatic ecosystems in Czechoslovakia or Norway. One previously studied strain (strain IP 5850) was isolated from soil in France (8). $Y$. aldovae has not been implicated in animal infections and has not been isolated from humans. It may be isolated from many of the same water sources as $Y$. enterocolitica. Therefore, clinical and environmental microbiologists should be able to distiguish these species from one another.

We propose the name Yersinia aldovae sp. nov. (al. do' vae. M. L. gen. n. aldovae in honor of Eva Aldova, the
Czechoslovakian microbiologist who first isolated this bacterium) for the Yersinia group formerly referred to as group X2. The type strain of $Y$. aldovae is strain CNY 6005 (= ATCC $35236=$ IP $6005=$ Al $19955=$ CDC 669-83); it was isolated by $\mathrm{E}$. Aldova from drinking water in Czechoslovakia.

Description of Yersinia aldovae sp. nov. The phenotypic characteristics of $Y$. aldovae fit the definition of the Enterobacteriaceae. $Y$. aldovae cells are gram negative, nonsporeforming, non-encapsulated, straight, and rod shaped and have peritrichous or degeneratively peritrichous fiagella when they are grown at $28^{\circ} \mathrm{C}$, but not when they are grown at $37^{\circ} \mathrm{C} ; 2$ to 10 flagella are usually present. $Y$. aldovae $\mathrm{CNY}$ $6005^{\mathrm{T}}$ grown for $48 \mathrm{~h}$ at $28^{\circ} \mathrm{C}$ aerobically on nutrient agar produces both small (diameter, $0.5 \mathrm{~mm}$ ) and medium-sized (diameter, $2 \mathrm{~mm}$ ) colonies. The colonies are translucent and have smooth, entire edges.

All $Y$. aldovae strains give positive results in tests for betagalactosidase ( $o$-nitrophenyl- $\beta$-D-galactopyranoside), catalase, methyl red $\left(28\right.$ and $\left.36^{\circ} \mathrm{C}\right)$, nitrate reduction to nitrite by type $B$ nitrate reductase, ornithine decarboxylase, the Voges-Proskauer reaction at $28^{\circ} \mathrm{C}$, and acid production from L-arabinose, esculin, D-fructose, galactose, $N$-acetyl-glucosamine, D-glucose, glycerol, D-mannitol, D-mannose, L-rhamnose, ribose, D-sorbitol, trehalose, and D-xylose. All $Y$. aldovae strains give negative results in tests for arginine dihydrolase, citrate (Simmons) $\left(36^{\circ} \mathrm{C}\right)$, deoxyribonuclease, gas from D-glucose, gelatin liquefaction (film), $\mathrm{H}_{2} \mathrm{~S}$ (Kligler), indole, lysine decarboxylase, malonate, motility at $36^{\circ} \mathrm{C}$, oxidase, phenylalanine deaminase, tetrathionate reductase, tryptophan deaminase, the Voges-Proskauer reaction at $36^{\circ} \mathrm{C}$, beta-xylosidase $\left(36^{\circ} \mathrm{C}\right)$, and acid production from adonitol, amygdalin, D-arabinose, arbutin, D-cellobiose, dulcitol, erythritol, lactose, melibiose, melizitose, alpha-methyl-D-glucoside, alpha-methyl-D-mannoside, alpha-methylxyloside, raffinose, salicin, $\mathrm{L}$-sorbose, and L-xylose. At least $95 \%$ of the strains are positive in tests for i-inositol, motility at $28^{\circ} \mathrm{C}$, and urease. All but two of our strains are sucrose negative after $48 \mathrm{~h}$.

The guanine-plus-cytosine content of the DNA of the type strain is $48 \mathrm{~mol} \%$.

All of our $Y$. aldovae strains except strain IP 5850 were isolated from aquatic ecosystems (drinking water, river water, fish); strain IP 5850 was isolated from soil. None was associated with disease in humans or animals. 
The type strain is CNY 6005 (= ATCC $35236=$ IP $6005=$ Al $19955=$ CDC 669-83)

Description of the type strain. Some characteristics of the type strain are given in Table 2. Other characteristics are as given above for the species. This strain is serologically untypable and belongs to phage type $X_{0}$.

\section{ACKNOWLEDGMENT}

We are grateful to H. H. Mollaret for making his culture collection and laboratory facilities available to us and for his continuing advice and encouragement during the course of this study.

\section{LITERATURE CITED}

1. Bercovier, H., J. M. Alonso, Z. N. Bentaiba, J. Brault, and H. H. Mollaret. 1979. Contribution to the definition and taxonomy of Yersinia enterocolitica. Contrib. Microbiol. Immunol. 5:12-22.

2. Bercovier, H., J. Brault, N. Barre, M. Treignier, J. M. Alonso, and H. H. Mollaret. 1978. Biochemical, serological and phage typing characteristics of 459 Yersinia strains isolated from a terrestrial ecosystem. Curr. Microbiol. 1:353-357.

3. Bercovier, H., D. J. Brenner, J. Ursing, A. G. Steigerwalt, G. R. Fanning, J. M. Alonso, G. P. Carter, and H. H. Mollaret. 1980. Characterization of Yersinia enterocolitica sensu stricto. Curr. Microbiol. 4:201-206.

4. Bercovier, H., H. H. Mollaret, J. M. Alonso, J. Brault, G. R. Fanning, A. G. Steigerwalt, and D. J. Brenner. 1980. Intra- and interspecies relatedness of Yersinia pestis by DNA hybridization and its relationship to Yersinia pseudotuberculosis. Curr. Microbiol. 4:225-229.

5. Bercovier, H., J. Ursing, D. J. Brenner, A. G. Steigerwalt, G. R. Fanning, G. P. Carter, and H. H. Mollaret. 1980. Yersinia kristensenii: a new species of Enterobacteriaceae composed of sucrose-negative strains (formerly called atypical Yersinia enterocolitica or Yersinia enterocolitica-like). Curr. Microbiol. 4:219-224.

6. Brenner, D. J., H. Bercovier, J. Ursing, J. M. Alonso, A. G. Steigerwalt, G. R. Fanning, G. P. Carter, and H. H. Mollaret. 1980. Yersinia intermedia: a new species of Enterobacteriaceae composed of rhamnose-positive, raffinose-positive strains (formerly called Yersinia enterocolitica or Yersinia enterocoliticalike). Curr. Microbiol. 4:207-212.
7. Brenner, D. J., A. C. McWhorter, J. K. Leete-Knutson, and A. G. Steigerwalt. 1982. Escherichia vulneris: a new species of Enterobacteriaceae associated with human wounds. J. Clin. Microbiol. 15:1133-1140.

8. Brenner, D. J., J. Ursing, H. Bercovier, A. G. Steigerwalt, G. R. Fanning, J. M. Alonso, and H. H. Mollaret. 1980. Deoxyribonucleic acid relatedness in Yersinia enterocolitica and Yersinia enterocolitica-like organisms. Curr. Microbiol. 4:195-200.

9. Ewing, W. H., A. J. Ross, D. J. Brenner, B. R. Davis, and G. R. Fanning. 1978. Yersinia ruckeri sp. n., the RM bacterium. Int. J. Syst. Bacteriol. 28:37-44.

10. Farmer, J. J., III. 1983. Biochemical chart for identifying the named species and "enteric groups" of Enterobacteriaceae. Centers for Disease Control, Atlanta, Ga.

11. Guinée, P. A. M., and J. J. Valkenburg. 1968. Diagnostic value of a Hafnia-specific bacteriophage. J. Bacteriol. 96:564.

12. Hickman, F. W., and J. J. Farmer III. 1978. Salmonella typhi: identification, antibiograms, serology, and bacteriophage typing. Am. J. Med. Technol. 44:1149-1159.

13. Hickman, F. W., J. J. Farmer III, D. G. Hollis, G. R. Fanning, A. G. Steigerwalt, R. E. Weaver, and D. J. Brenner. 1982. Identification of Vibrio hollisae sp. nov. from patients with diarrhea. J. Clin. Microbiol. 15:395-401.

14. Mandel, M., and J. Marmur. 1968. Use of ultraviolet absorbance-temperature profile for determining the guanine plus cytosine content of DNA. Methods Enzymol. 12B:195-206.

15. Owen, R. J., L. R. Hill, and S. P. Lapage. 1969. Determination of DNA base compositions from melting profiles in dilute buffers. Biopolymers 7:506-516.

16. Popoff, M., and C. Coynault. 1980 . Use of DEAE-cellulose filters in the S1 nuclease method for bacterial deoxyribonucleic acid hybridization. Ann. Microbiol. (Paris) 131A:151-155.

17. Richard, C., and J. M. Alonso. 1976. Une entérobactérie méconnue: Enterobacter hafniae. Bull. Inst. Pasteur (Paris) 74:339-352.

18. Ursing, J., D. J. Brenner, H. Bercovier, G. R. Fanning, A. G. Steigerwalt, J. Brault, and H. H. Mollaret. 1980. Yersinia frederiksenii: a new species of Enterobacteriaceae composed of rhamnose-positive strains (formerly called atypical Yersinia enterocolitica or Yersinia enterocolitica-like). Curr. Microbiol. 4:213-217.

19. Wauters, G., L. Le Minor, A. M. Chalon, and J. Lassen. 1972. Supplément au schéma antigénique de Yersinia enterocolitica. Ann. Inst. Pasteur (Paris) 122:951-956. 